\title{
Initiation and Maintenance Mechanisms for Heavy Precipitation System over a Mountainous Island under a Prevailing Monsoon Current
}

\author{
Y.-L. Lin ${ }^{1,2}$, K.-Y. Lee ${ }^{3}$, C.-S. Chen ${ }^{3}$, F.-Y. Cheng ${ }^{3}$, P.-L. Lin ${ }^{3}$, J.-H. Teng ${ }^{4} \&$ C.-L. Liu ${ }^{3}$ \\ ${ }^{1}$ Department of Physics, North Carolina A\&T State University, NC 27411 USA \\ ${ }^{2}$ Department of Energy \& Environmental Systems, North Carolina A\&T State University, NC 27411 USA \\ ${ }^{3}$ Institute of Atmospheric Physics, National Central University, Chung-Li, 32001 Taiwan \\ ${ }^{4}$ Research and Development Center, Central Weather Bureau, Taipei, 10048 Taiwan \\ Correspondence: Yuh-Lang Lin, 302H, Gibbs Hall, EES/ISET, NC A\&T State University, 1601 E. Market Street, \\ 27411, USA. Tel: 1-336-285-2127. E-mail: ylin@ncat.edu
}

Received: April 22, 2016

Accepted: May 5, 2016

Online Published: May 20, 2016

doi:10.5539/esr.v5n2p90

URL: http://dx.doi.org/10.5539/esr.v5n2p90

\begin{abstract}
In this study, the initiation and maintenance mechanisms of two long-lived, summer heavy rainfall systems over Taiwan are investigated by performing observational data analyses and numerical simulations using a mesoscale model. For both cases of 9-10 July 2008 (Case A) and 18-19 August 2006 (Case B), the heavy rainfall system developed over the western slope of the Central Mountain Range (CMR) under low-level prevailing southwesterly and westerly flows in early afternoon, respectively. These heavy rainfall systems were moving westward toward Taiwan Strait from CMR, while the embedded individual cells were moving in the opposite direction, behaving like a multicell storm. It was also found these individual cells were initiated, enhanced, and then maintained at the leading edge of the near-surface cool outflow and merged with the heavy rainfall systems which became long-lived. These heavy rainfall systems were classified as an upstream propagating precipitation system in a low Froude-number, conditionally unstable flow with high convective available potential energy (CAPE) or Regime I as proposed in a previous study.
\end{abstract}

Keywords: heavy precipitation, orographic rain, convective cells, multicell storms, Central Mountain Range

\section{Introduction}

Orographic precipitation initiated by sensible heating and enhanced and maintained by convective cells over slopes of a mountainous island in a prevailing wind is still not well understood, thus deserves further studies. For example, summer precipitation in Taiwan is strongly influenced by the southwesterly monsoon which brings in warm, moist maritime air from the southwest (Chen \& Chen, 2003). The major summer rainfall contributions are the rainshowers associated with tropical disturbances and those induced by the local terrain with a pronounced afternoon peak because approximately two-thirds of Taiwan are occupied by mountains, including the Central Mountain Range (CMR) and Snow Mountain Range (SMR) (Fig. 1) (Chen \& Chen, 2003; Kerns et al., 2010). Since the prevailing monsoon current is from southwest, the maximum accumulated rainfall associated with local rainshowers is over the western windward slopes of the north northeast-south southwest oriented mountain (Chen \& Chen, 2003; Kerns et al., 2010; Wang \& Chen, 2008; Lin et al., 2011).

The local rainshowers can contribute up to $40-50 \%$ of the total rainfall in July and August (Wang \& Chen, 2008). The hourly averaged rainfall rate of the local rainshowers under weak synoptic-scale forcing often reaches a maximum over the southwestern slope of CMR between 1500 and 1700 LST (UTC $+8 \mathrm{~h}$ ) and decreases substantially until midnight over Taiwan (Lin et al., 2011; Kerns et al., 2010). Over the low lands of the western and southwestern Taiwan, rainfall maximum occurs in the evening transition period, instead of in the period of 1500-1700 LST (Kerns et al., 2010). The frequency of occurrence of radar echoes over the western and southwestern coast of Taiwan reaches their maximum during 1700-1800 LST (Fig. 5 of Lin et al., 2011). Over the adjacent oceans in southern Taiwan Strait, the estimated rainfall by the Tropical Rainfall Measuring Mission 
(TRMM) for May-September 1988 also has a diurnal cycle with a late-night to early-morning maximum (Krishtawal \& Krishnamurti, 2001). The late night-early morning maximum in windward coastal areas is also observed over other parts of the world, such as Indochina Peninsula (Ohsawa et al., 2001). Rainfall over the adjacent ocean near the coast, which may play an important role on the hydrological cycle over ocean, may be resulted from the complicated interactions of the offshore flow associated with inland convection and the prevailing wind (Houze et al., 1981; Kerns et al., 2010; Ohsawa et al., 2001 among others). Although the dynamic of orographic effects on the generation and maintenance of convection are reasonably well understood (Lin, 2007; Chen, 2000), convection over an isolated mountainous island surrounded by oceans, such as convection over Taiwan, is less well understood.

Over the windward slopes of CMR, convection is often triggered upstream and/or upslope (Lin, 1993; Chen et al., 2005, 2011; Lin \& Chen, 2002). It was found that the interaction of prevailing winds with the cool air produced by evaporative cooling may generate and maintain convection. In a low moist Froude number $\left(\mathrm{F}_{\mathrm{w}}\right)$ regime (e.g., $\mathrm{F}_{\mathrm{w}} \leqq 0.34$ ), a convective system over the mountain slope may propagate upstream against the prevailing wind, such as the southwesterly monsoon in the current study, due to cooler and denser air associated with the density current and become a long-lived convective system (Chu \& Lin, 2000; Lin, 2007). Here, $F_{w}$ is defined as $\mathrm{F}_{\mathrm{w}}=\mathrm{U} / \mathrm{N}_{\mathrm{w}} \mathrm{h}$ (Chen \& Lin, 2005; Lin, 2007), where $\mathrm{U}$ is the upstream basic flow speed perpendicular to the mountain range (approximately zonal flow for the current case), $\mathrm{N}_{\mathrm{w}}$ is the unsaturated moist Brunt-Väisälä frequency, and $\mathrm{h}$ is the mountain height. Besides, when the precipitation system propagates to the coastal area, the low-level cooler air associated with the precipitation system tends to interact with the southwesterly monsoon current to facilitate the development of new convections over the adjacent coastal area and ocean.

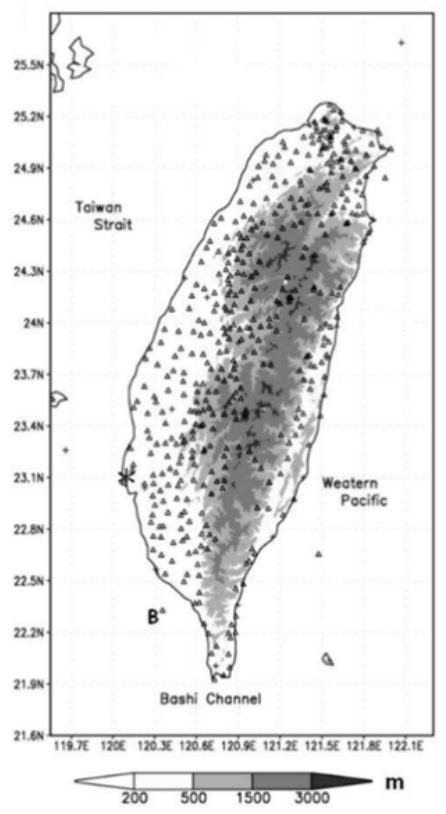

Figure 1. Distribution of twenty-five conventional stations (crosses) and rainfall stations from the Automatic Rainfall and Meteorological Telemetry System (ARMTS; triangles) in Taiwan. The grayscale shows terrain elevations in meters. B stands for a buoy station off southwestern Taiwan coast. The Chi-Gu Doppler radar is indicated by a star symbol

According to Kerns et al. (2010), the westward-movement of local rainshowers from CMR to Taiwan Strait is frequently observed in summer. In studying the summer rainshowers over southwestern Taiwan for the period of 2005-2010, Lee (2012) recently found that in average there are 22 local rainshower days per year (132 days in total), which have daily accumulated rainfall exceeding $50 \mathrm{~mm}$. The average rainfall period over the entire region of southwestern Taiwan due to this type of local rainshowers is about $7.5 \mathrm{~h}$. There are 5 (25) rainfall days whose rainfall period is over 10 hours with accumulated rainfall exceeding $130(50) \mathrm{mm} \mathrm{d}^{-1}$ during this period. These long-lived convective systems initiated over the western slopes of Taiwan's CMR may propagate more than $50 \mathrm{~km}$ westward against the southwesterly monsoonal flow toward Taiwan Strait. These long-lived convective systems tend to produce relatively large amount of rainfall, often associated with cooler air, which affect western low-land areas. Many previous studies have conducted statistical studies of local rainshowers over 
the landmass of Taiwan in summer (Lin et al., 2011; Kerns et al., 2010; Wang \& Chen, 2008), however, there is a lack of case studies on the mechanisms responsible for producing long-lived heavy rainfall convective systems. Their findings lead us to pursue the abovementioned mechanisms for producing long lasting (exceeding $10 \mathrm{~h}$ ) summer heavy rainfall systems.

In this study, we propose that (1) a series of individual convective cells are initiated by the cold downslope outflow produced by preexisting convective cells move against the southwesterly prevailing wind; and (2) The low-Froude number, conditionally unstable flow makes the precipitation system propagates upstream (westward) while individual cells propagating downstream, behaving like Regime I proposed by Chen \& Lin (2005) and, in a way, analogous to a multicell storm. This paradigm will be verified by performing observational analyses of a variety of data sets, such as the NCEP analysis data, satellite imagery, radar reflectivity, and rainfall data, and numerical simulation using the Weather Research and Forecast model (WRF; Skamaock et al., 2008) to investigate the synoptic and mesoscale processes and to test our hypothesis on the initiation and maintenance of these long-lived convective systems.

\section{Observational Data Analysis}

\subsection{Data Characteristics}

Our synoptic analyses around Taiwan are based on the NCEP data in $1^{\circ} \mathrm{x} 1^{\circ}$ resolution. Rainfall data comes from the 250 ARMTS stations over the island (Chen et al., 2007). Radar reflectivity with 7.5 min time interval and $1 \mathrm{~km} \times 1 \mathrm{~km}$ spatial resolution is from CWB's Chi-Gu Doppler radar (Fig. 1). Due to the limitation of available radar data, cases A (9-10 July 2008) and B (18-19 August 2006) among the 5 long-lived heavy rainfall events mentioned in the introduction are selected for investigation in this study. The accumulated daily rainfall amount was greater than $130 \mathrm{~mm}$ in each case (Fig. 2), which is defined as heavy rainfall by Central Weather Bureau (CWB).
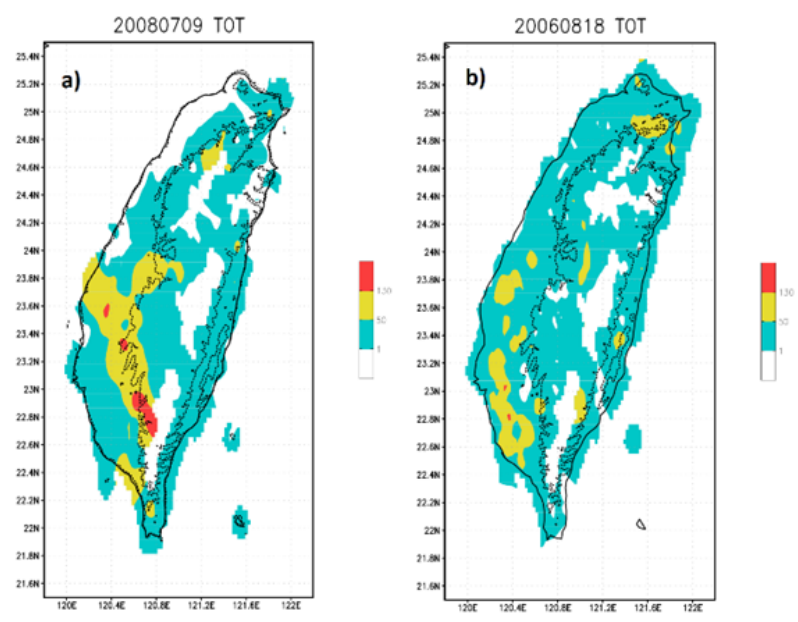

Figure 2. The daily rainfall accumulation (mm in color). (a) 9 July 2008 and (b) 18 August 2006. The terrain elevation is shown at $500 \mathrm{~m}$ (solid line)

\subsection{Case A (9-10 July 2008)}

At 08 LST 9 July 2008 (7/9/08 LST), a low pressure system at $850 \mathrm{hPa}$ was situated over northern Vietnam coast and a monsoon trough extended southeastward to western South China Sea (SCS) (Fig. 3a). Meanwhile, the western Pacific high pressure extended to The Philippines resulting in southwesterly flow over northern SCS, Taiwan Strait, and Taiwan. The flow pattern is similar to Monsoon I type proposed by Ko \& Tzeng (2013). The low-level prevailing southwesterly wind speed was about $8.8 \mathrm{~m} \mathrm{~s}^{-1}$ and the $\mathrm{F}_{\mathrm{w}}$ is about $0.3(\mathrm{~h} \sim 2500 \mathrm{~m}$ and $\mathrm{N}_{\mathrm{w}} \sim 0.01 \mathrm{~s}^{-1}$ ). In addition, Taiwan was under a $200-\mathrm{hPa}$ divergent area over the eastern edge of the Tibetan high (not shown). The direction of the low-level prevailing wind is different from that of the upper-level wind. The lifting condensation level (LFC) was around $875 \mathrm{hPa}$ and weak descending motion (ascending motion) occurred below (above) the $750 \mathrm{hPa}$ over Taiwan Strait (Lee, 2012). Over the mountains, radar echoes occurred before noon (not shown) and intensified in the afternoon (Fig. 4a). Onshore and upslope flows were present over most coastal and sloped areas, respectively. Meanwhile, radar echoes over southern Taiwan Strait were also detected. Radar echoes from the mountains extended to the western slopes of CMR and formed a north northwest-south 
southeast line of echoes over southwestern Taiwan at 7/9/19 LST (Fig. 4b). Downslope flow was observed over the southwestern slopes.
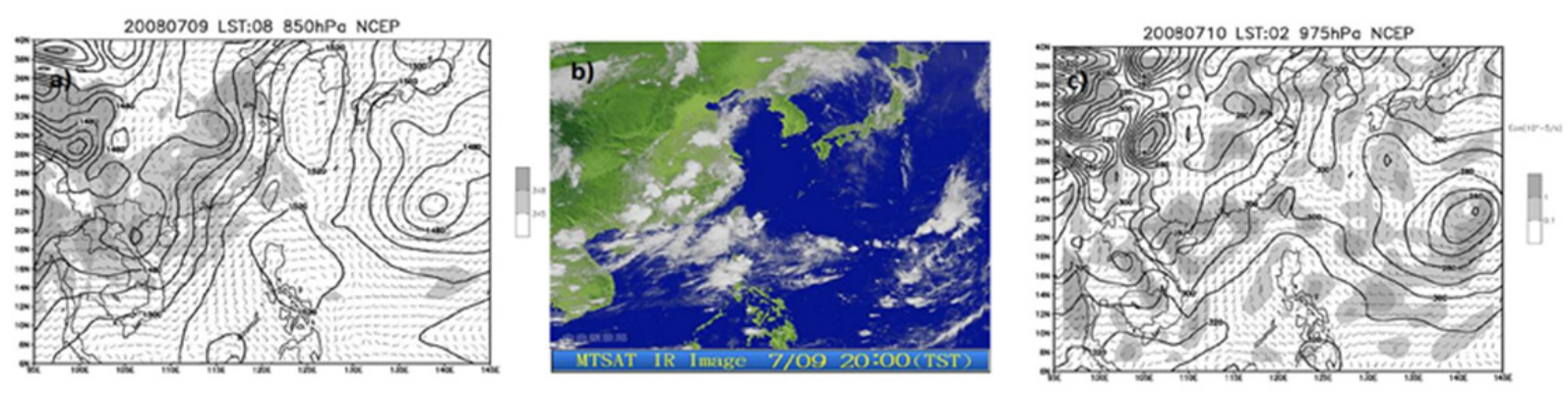

Figure 3. (a) The 850-hPa synoptic analysis at 7/9/08 LST 2008 from the NCEP data including geopotential heights (solid lines, 10 gpm contour interval) and winds (a full barb and a half barb represent 5 and $2.5 \mathrm{~m} \mathrm{~s}^{-1}$, respectively; also used for other figures). The grayscale represents the equivalent potential temperature in K. (b) Satellite image at 7/9/20 LST 2008. (c) Same as (a) but for $975 \mathrm{hPa}$ at 7/10/02 LST. The shaded areas represent the convergence in $10^{-5} \mathrm{~s}^{-1}$

Satellite images at 7/9/20 LST also showed a cloud line over southwestern Taiwan coast (Fig. 3b), corresponding to the line echo. The line echo over southwestern Taiwan in Fig. 4b moved westward to Taiwan Strait at 7/10/02 LST (Fig. 4c). Offshore flow and northerly flow occurred over southwestern coast and an island off southwestern coast, respectively. According to Lee (2012), there was about $2 \mathrm{~K}$ difference in potential temperature between the stations over southwestern coast and a buoy station offshore of the southwestern coast (see Fig. 1 for the location) in the early morning of 10 July. Apparently, the offshore flow interacted with prevailing southwestern wind over the adjacent ocean off southwestern coast to enhance convection there. In addition, a low-level mesoscale convergence zone can be seen in the southern Taiwan Strait (Fig. 3c) to help strengthen convection. The relatively high radar reflectivity over southeastern Taiwan Strait and the adjacent ocean of southwestern Taiwan is also shown in the hourly-averaged radar reflectivity during the period in 7/10/01-06 LST (Fig. 4d).
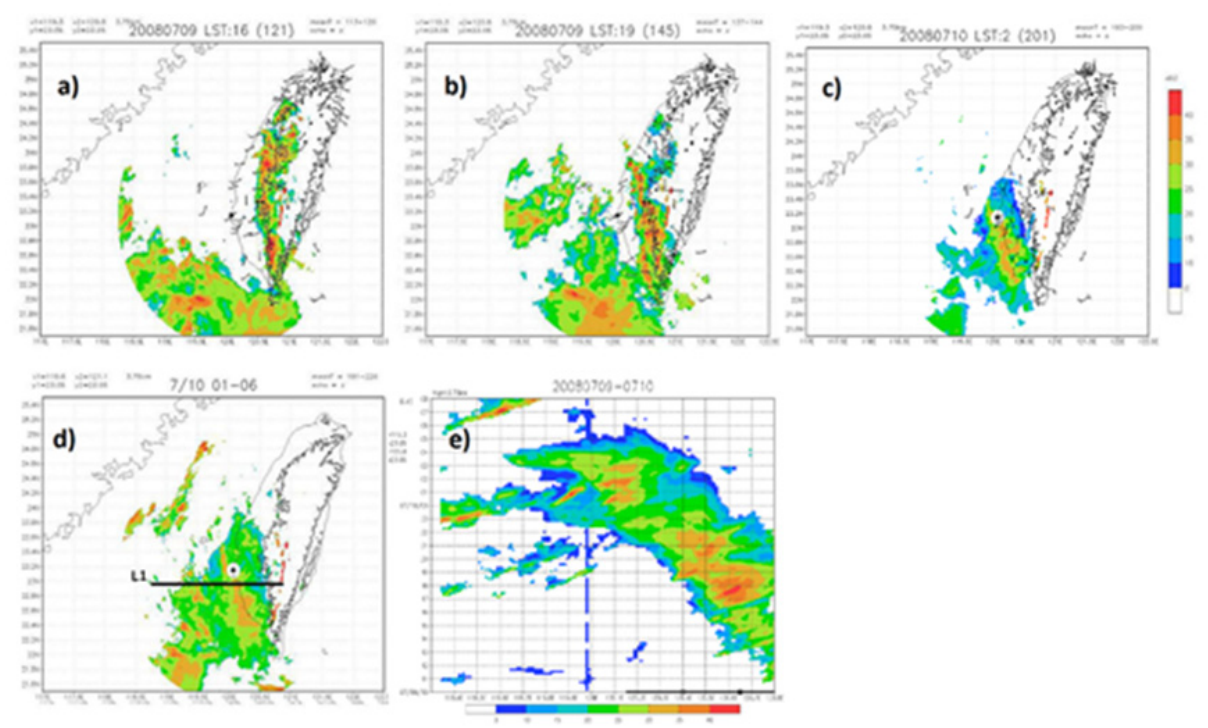

Figure 4. The radar echoes from Chi-Gu radar (dBZ in color). (a) 7/9/16 LST, (b) 7/9/19 LST, and (c) 7/10/02 LST; (d) The average radar echoes from 7/10/01 to 7/10/06 LST 2008; (e) The evolution of radar echoes along line L1 in (d) from 7/9/10 LST to 7/10/08 LST 2008. Open and closed squares represent the elevation at 100 and $500 \mathrm{~m}$, respectively. The terrain elevation is shown at $500 \mathrm{~m}$ (solid line). Note that the intense, stationary, and north-south oriented line echoes (greater than $35 \mathrm{dBZ}$ ) in between $22.4-23.7^{\circ} \mathrm{E}$ and $120.5-121^{\circ} \mathrm{E}$ are the ground clutter associated with high mountains of the CMR

The evolution of those radar echoes from the western slope of CMR to the adjacent ocean of southern Taiwan 
can be illustrated in more detail at constant height of $3.75 \mathrm{~km}$ with $7.5 \mathrm{~min}$ interval (Fig. 4e) along L1 over southwestern Taiwan (Fig. 4d). L1 passed the salient westward-movement convection system from southwestern slope of the CMR to the adjacent ocean and high accumulated rainfall area (Fig. 2a). The radar echoes are averaged perpendicular to L1 over a distance of about $10 \mathrm{~km}$. Before 7/9/12 LST, convection occurred over mountains. While the convective system moved westward in the afternoon, convective cells moved eastward influenced by the prevailing southwesterly winds. This phenomenon belongs to Regime I, i.e. low $F_{w}$, conditionally unstable flow with high CAPE over mountains as proposed by Chen \& Lin (2005). Note that Chen \& Lin's categorization of conditionally unstable moist flow regime was based on Chu \& Lin (2000), but added CAPE as another parameter in determining the flow regimes. In the present case, the CAPE is $1258 \mathrm{~J} \mathrm{~kg}^{-1}$, which is considered to be high enough to form deep convective cells. The convective system arrived at the coast around 7/9/22 LST and remained there until 7/10/05 LST. From late night of 9 July till early morning of 10 July, radar echoes from adjacent ocean of southwestern Taiwan moved onshore and merged with the westward-movement of precipitation system over the coastal areas (Fig. 4e). The precipitation system formed over mountainous area before noon on 9 July and propagated toward Taiwan Strait in the morning on 10 July. The lifespan of this precipitation system exceeded 12 hours. The mechanisms for maintaining the long-lived rainfall system will be examined in section 3 .

\subsection{Case B (18-19 August 2006)}

At 8/18/08 LST, Typhoon Wukong was located over southwestern Japan (Fig. 5a) on $850 \mathrm{hPa}$. The northerly wind associated with Wukong's outer circulation over southeastern China coast converged with westerly wind over southern Taiwan Strait and northeastern SCS. The flow pattern is similar to Monsoon I-TC type proposed by Ko \& Tzeng (2013). The westerly wind was about $3 \mathrm{~ms}^{-1}$, which gave a low $\mathrm{F}_{\mathrm{w}} \sim 0.15$. At upper levels, Tibet high dominated the East Asia and a divergent area was found over southern Taiwan Strait and northeastern SCS (not shown). The direction of the low-level prevailing wind is different from that in the upper level. The LFC was around $900 \mathrm{hPa}$ and an ascending motion occurred above the $950 \mathrm{hPa}$ over the Taiwan Strait (Lee, 2012). At 8/18/09 LST, radar echoes were located over the southwestern coast of Taiwan (not shown). By 8/18/11 LST, a north-south oriented line of radar echoes extended from the central to southern coast (Fig. 6a).
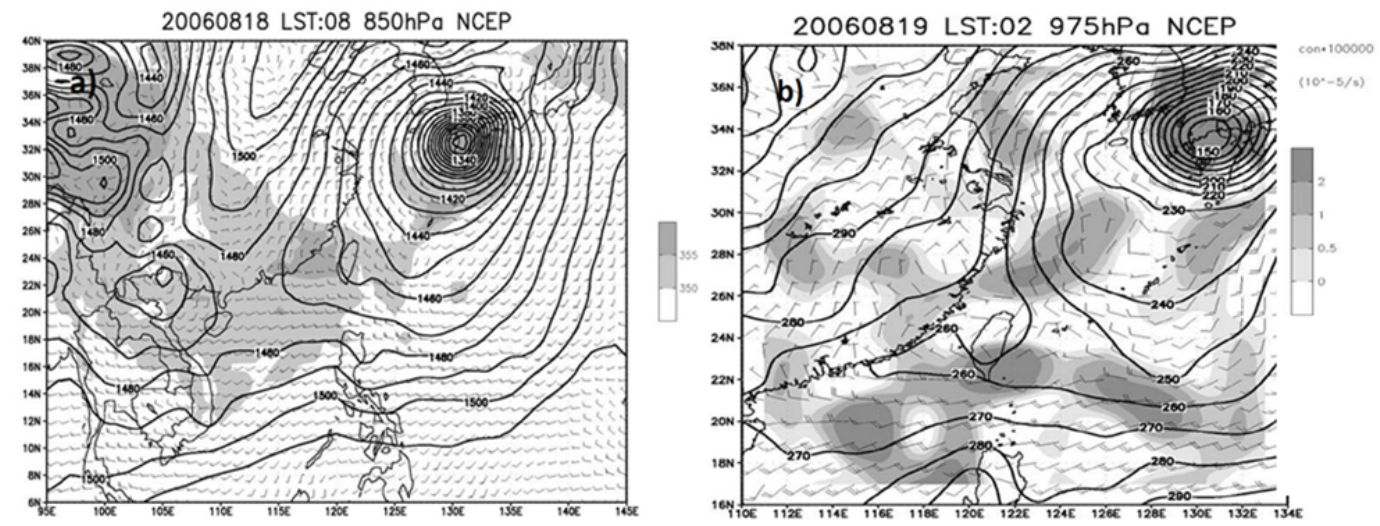

Figure 5. (a) Same as Fig. 3a but for 18 August 2006. (b) Same as Fig. 3c, but for 19 August 2006

Meanwhile, relatively higher radar echoes also appeared over the western slope of the CMR. Similar to Case A, onshore and upslope flows were present over most coastal and sloped areas, respectively. The relatively high reflectivity area associated with this north-south oriented line of radar echoes moved eastward to CMR can also be seen from Fig. 6e. Around 8/18/15 LST, this radar-echo line moved westward from the mountain slope to Taiwan Strait (Fig. 6b) and the downslope flow occurred over the southwestern sloped areas. Although convective cells weakened over the adjacent ocean near southwestern Taiwan in the evening of 18 August (not shown), they intensified in early morning the next day (Fig. 6c). Offshore flow occurred over the southwestern coast and interacted with prevailing westerly wind to help convective cells develop over the area from southwestern Taiwan to southeastern Taiwan Strait. According to Lee (2012), there were about 1 to $2 \mathrm{~K}$ difference in potential temperature between the stations over southwestern coast and a buoy station offshore of the southwestern coast in the early morning of 19 August. Meanwhile, a low-level mesocale convergence region was found over northeastern SCS and southern Taiwan Strait to strengthen convection there (Fig. 5b). The hourly-averaged radar reflectivity from 8/19/01-06 LST shows that higher radar reflectivity was present over the coast and adjacent ocean (Fig. 6d) with local maximum appeared over the ocean near coastal area and 
southeastern Taiwan Strait.

The evolution of radar echo from the western slope of CMR to the adjacent ocean is illustrated in more detail
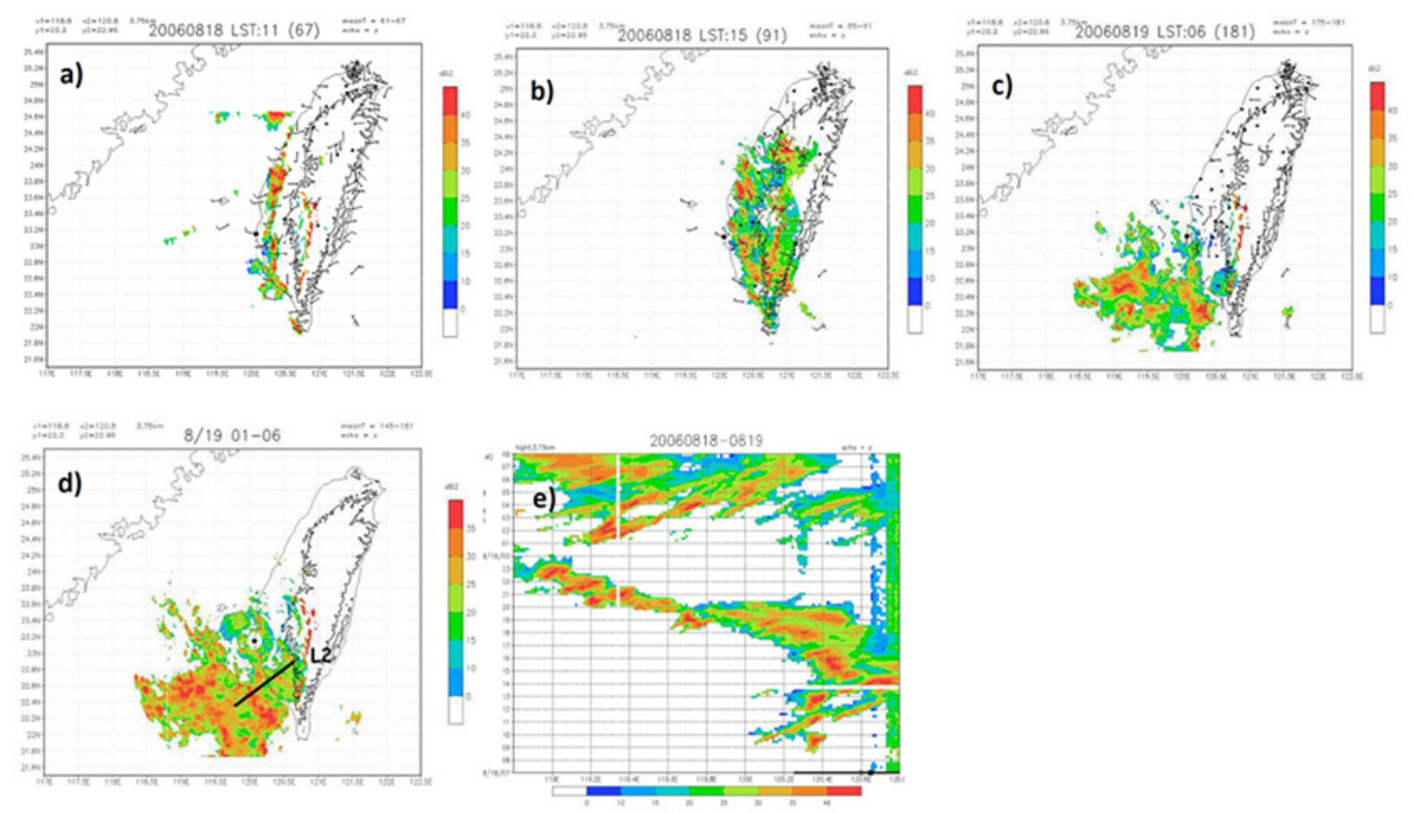

Figure 6. (a) Same as Fig. 4 a but for 8/18/11 LST 2006. (b) Same as (a) but for 8/18/15 LST. (c) Same as (a) but for 8/19/06 LST. (d) Same as Fig. 4d but for 8/19/01-06 LST 2006. (e) Same as Fig. 4e but for 8/18/07 LST to 8/19/08 LST 2006 along L2 (see Fig. 6d). Similar to Fig.4, the intense, stationary, and north-south oriented line echoes (greater than $35 \mathrm{dBZ}$ ) in between $22.4-23.7^{\circ} \mathrm{E}$ and $120.5-121^{\circ} \mathrm{E}$ are the ground clutter associated with

high mountains of the CMR

(Fig. 6e) along L2 over southern Taiwan (Fig. 6d) at $\mathrm{z}=3.75 \mathrm{~km}$. Note that $\mathrm{L} 2$ passes through the maximum daily accumulated rainfall area in southwestern lowland area (Fig. 2b). The radar echoes are averaged perpendicular to L2 over a distance of about $10 \mathrm{~km}$. Before 8/18/14 LST, radar echoes moved inland from adjacent ocean of southwestern Taiwan. After 8/18/15 LST, the convective system propagated toward ocean while individual convective cell moved eastward along with the westerly component of the wind (Fig. 5a). In the late night of 18 August, the southwestward movement of convective system interacted with the northeastward movement of convective cells over the nearby ocean of southwestern Taiwan (Fig. 6e). In the early morning of 19 August, enhanced convection over the adjacent ocean of southwestern Taiwan moved back toward coastal area (Fig. 6e).

Similar to the precipitation system of Case A, which belonged to Regime I of Chen \& Lin (2005) since the $\mathrm{F}_{\mathrm{w}}$ is low and CAPE $\left(2652 \mathrm{~J} \mathrm{~kg}^{-1}\right)$ is high. The cold pool of air produced by the precipitation system of Case B propagated upstream against the low-level wind toward southern Taiwan Strait. The lifespan of the precipitation system is over $12 \mathrm{~h}$. However, convection over the adjacent ocean of southwestern Taiwan coast in the early morning is stronger in case B. The mechanisms for maintaining the precipitation system and making it long-lived will be examined in next Section.

\section{Experiment Design and Simulation Results}

\subsection{Experimental Design}

The WRF model is employed to simulate the above described events with Domains 1, 2, and 3 with horizontal grid interval of 27, 9 and $3 \mathrm{~km}$ respectively. The domain configurations for Cases A and B are shown in Fig. 7. All grids are comprised of 31 vertical levels from the surface to $50 \mathrm{hPa}$. In Domains 1 and 2, cumulus convection is parameterized by Kain \& Fritsch scheme (1993) for Case A and Grell-Devenyi ensemble scheme (Grell \& Devenyi, 2002) for Case B. The microphysical processes are parameterized by the Thompson scheme (Thompson et al., 2008) for both cases. For Domain 3, the convective parameterization is deactivated. The Yonsei University PBL parameterization (Hong et al., 2006) is used to represent the planetary boundary layer processes. The land surface model is the 5-layer thermal diffusion model (Dudhia, 1996). The model is 
initialized from the NECP FNL analysis at 7/8/20 LST (12 UTC) 2008 and 8/17/20 LST 2006 for Case A and B, respectively. All simulations are integrated for $36 \mathrm{~h}$. In order to examine the impacts of the evaporative cooling associated with raindrops on the development of long-lived heavy rainfall system, the experiment with evaporative cooling deactivated (NEV) is performed.
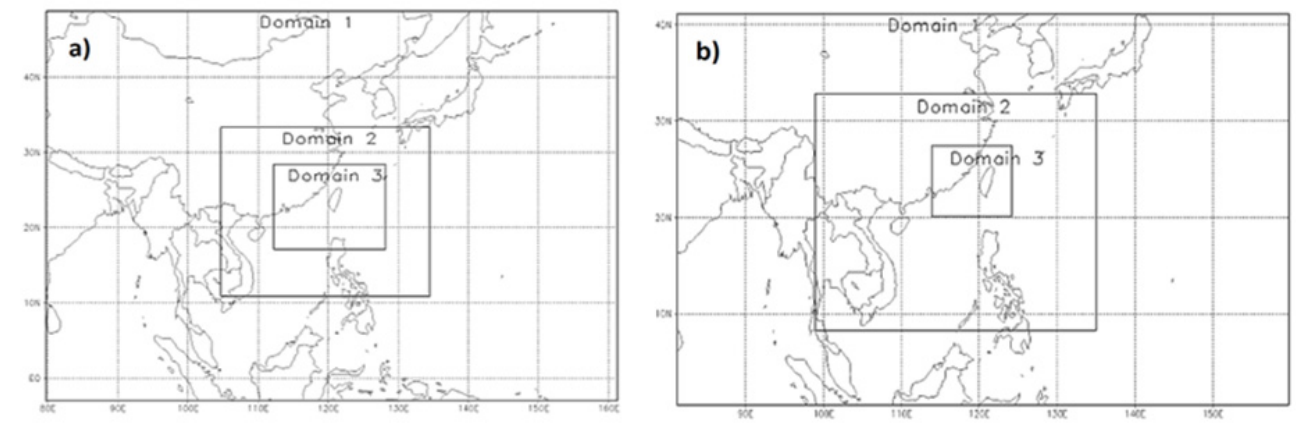

Figure 7. Configurations of the model simulation domains for (a) case A and (b) case B. The horizontal grid sizes for Domains 1-3 are 27, 9 and $3 \mathrm{~km}$, respectively

\subsection{Simulation Results}

\subsubsection{Case A (9-10 July 2008)}

The simulated 850-hPa synoptic environment at 7/9/08 LST before the occurrence of long-lived precipitation system is shown in Fig. 8a. The simulated high pressure over the East China Sea and the Philippines and the low pressure over China are similar to those observed (Fig. 3a). However, the simulated low pressure over northern
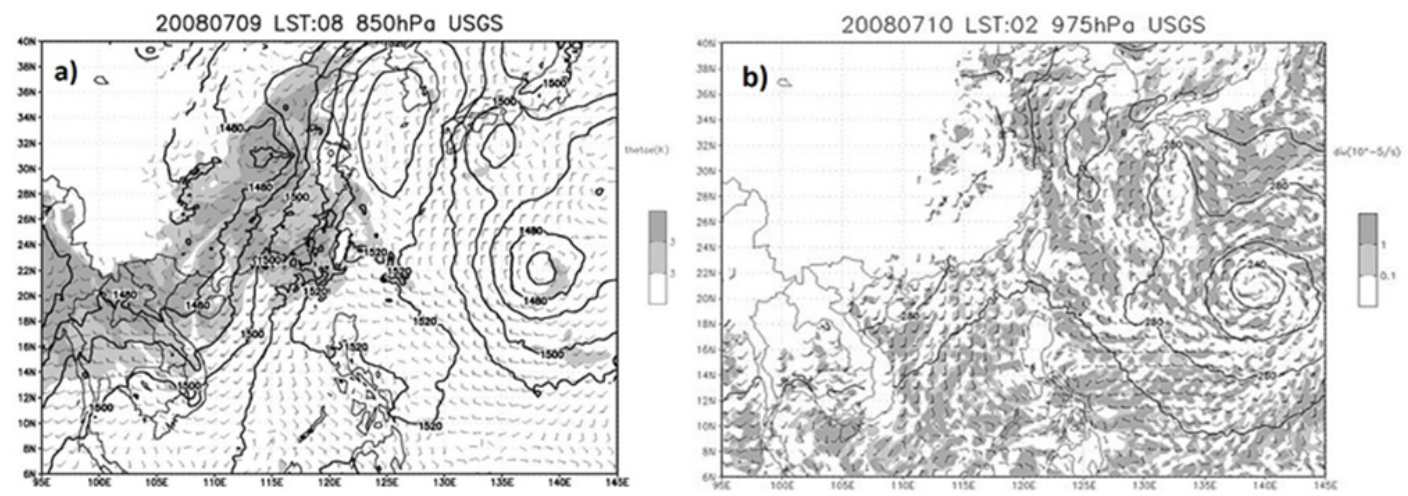

Figure 8. (a) The simulated 850-hPa geopotential height (solid lines, 10 gpm contour interval), winds and equivalent potential temperature (gray scale in K) in Domain 1 (27 km grid interval) at 7/9/08 LST 2008. (b)

Same as (a) but for $975 \mathrm{hPa}$ at 7/10/02 LST. The contour interval for geopotential height is $20 \mathrm{gpm}$. The convergence is represented by gray scale in $10^{-5} \mathrm{~s}^{-1}$

Vietnam coast and the monsoon trough over western SCS were weaker than those observed resulting in a slightly weaker southwesterly flow (Lee, 2012). The simulated rainfall formed over the western mountainous area of CMR at 7/9/11 LST (not shown) and intensified over the western slope of CMR at 7/9/16 LST (Fig. 9a) which was consistent with observations (Fig. 4a). The simulated rainfall over southern Taiwan Strait and southern coast of Taiwan, and the simulated onshore and upslope flows over western Taiwan are similar to the observations (Fig. 4a). The simulated rainfall propagated westward toward the coast at 7/9/18 LST (Fig. 9b). In the meantime, some convective cells, which formed near the coastal area, were moving onshore (not shown). These phenomena are similar to observations (Figs. 4a and 4b). In the early morning of 10 July, no rainfall was found over the adjacent ocean near southwestern Taiwan in the simulation (not shown), which is not consistent with observations (Fig. 4c). Most of the rainfall on 9 July (Fig. 9c) was over the mountainous and sloped areas, similar to observations (Fig. 2a). But, the magnitude of the simulated rainfall over western slope in central Taiwan is higher than that observed. The simulated local maximum rainfall over southwestern coast and over the adjacent ocean of 
southern Taiwan Strait is consistent with observations (Lee, 2012).

The evolution of the simulated precipitation system is depicted by the simulated rainfall along line L1S over southwestern Taiwan, which is denoted in Fig. 9c, as shown in Fig. 10a. Line L1S is similar to line L1 in Fig. 4d. In the afternoon, the simulated precipitation system occurred over the mountain. The simulated convective cell (Cell A) moved from the slope eastward toward the mountain (Fig. 10a). Several convective cells (Cells B-F) also moved eastward after 7/9/13 LST. On the other hand, the whole precipitation system moved westward toward the low land and ocean. When those east-moving convective cells encountered the relatively cooler air (e.g. virtual potential temperature $\theta_{v}<303 \mathrm{~K}$ ) associated with the precipitation system at the low-land and
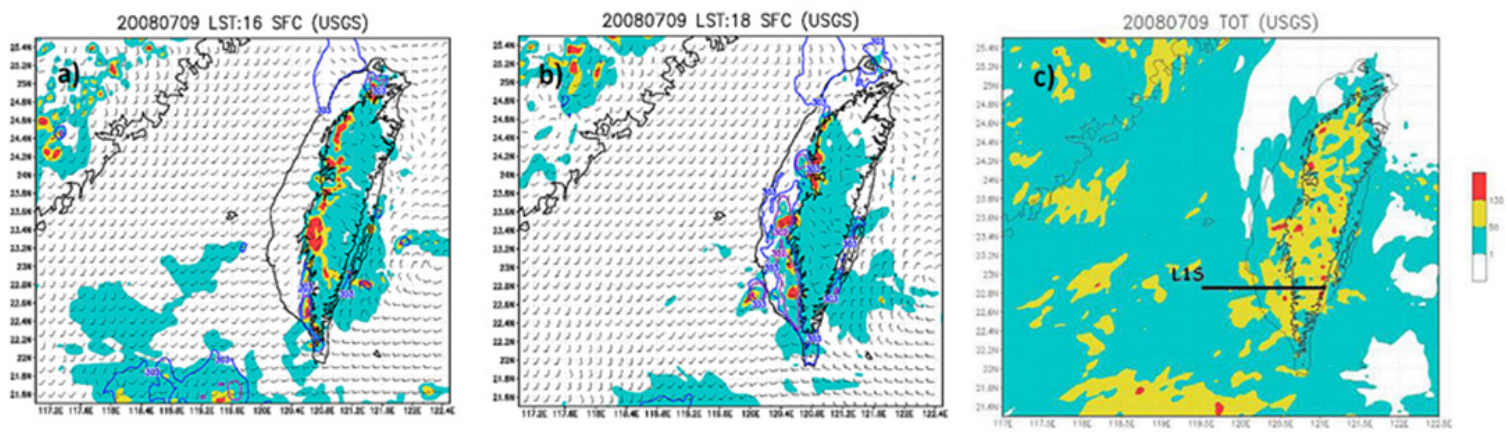

Figure 9. (a) Simulated hourly rainfall ( $\mathrm{mm}$ in color bar) and surface winds from Domain 3 ( $3 \mathrm{~km}$ grid interval) for (a) 7/9/16 LST 2008, and (b) 7/9/18 LST 2008. (c) The simulated accumulated daily rainfall (color bar in mm) on 9 July 2008. The simulated virtual potential temperature is represented by purple lines $(302 \mathrm{~K})$ and blue lines

$(303 \mathrm{~K})$. The terrain elevation is shown at $500 \mathrm{~m}$ (black solid line)

ocean, they intensified. The westward-movement of the simulated precipitation system is similar to that of radar echoes (Fig. 4e) except with more detailed formation of individual convective cells and their evolution depicted.

The mechanism for maintaining the long-lived precipitation system is examined through the analysis of the kinematic and thermodynamic fields (Fig. 11) along the vertical cross section of L1S (Fig. 9c). In the afternoon around 7/9/13 LST, the simulated precipitation system formed over mountain (Fig. 11a). Meanwhile, cell A
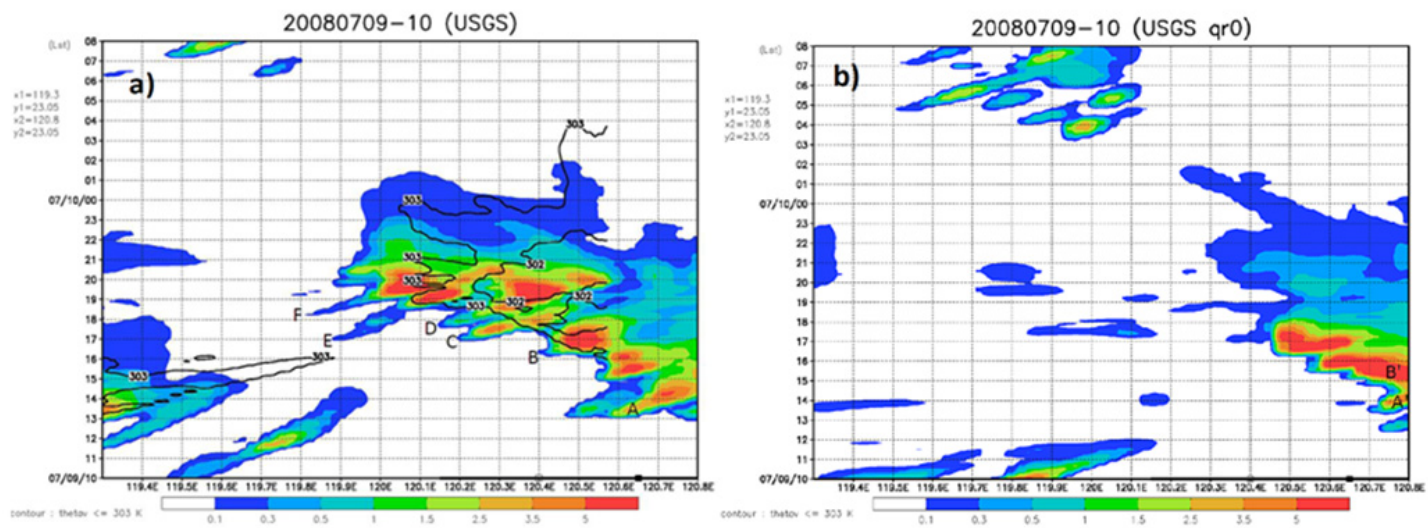

Figure 10. (a) Evolution of the simulated 10 min-accumulated rainfall ( $\mathrm{mm}$ in color bar) along L1S in Fig. 9c from $3 \mathrm{~km}$ grid size from 7/9/10 LST to 7/10/08 LST 2008. Open and closed squares represent the elevation at 100 and $500 \mathrm{~m}$, respectively. The virtual potential temperature at $975-\mathrm{hPa}$ level is shown at 302 and $303 \mathrm{~K}$ in black lines. (b) Same as (a) but for the NEV run

appeared over the plain area where a well-mixed boundary layer is formed. Cell A then moved toward the mountain slope and intensified since it is embedded in a conditionally unstable atmosphere (i.e., $\partial \theta_{e}^{*} / \partial z<0$ where $\theta_{e}^{*}$ is the saturated equivalent potential temperature) at 7/9/14 LST (Fig. 11b). At 7/9/16 LST, cell B formed over the coastal area (Fig. 11c) where an area of low-level convergence was present due to orographic lifting (Fig. 12a). Cell B intensified over the mountain foot area and merged with the westward moving precipitation system at 7/9/17 LST (Fig. 11d). A pool of cool air, approximately depicted by $\theta_{v}=303 \mathrm{~K}$ was 
produced below convective cell B. Meanwhile, cell C formed over the adjacent ocean where an area of low-level convergence existed (Fig. 12b). At 7/9/1730 LST, cell C intensified and moved eastward encountering the cool air associated with cell B (Fig. 11e). At this time, cell C merged with the westward moving precipitation system. As a result, the intensity of the precipitation was maintained. West (upstream) of cell C, cell D started to form where the westerly flow decelerated along coast and convergence was present (Fig. 12b). Similar to cell C, Cell $\mathrm{D}$ intensified when it encountered the cool pool generated by cell $\mathrm{C}$, then merged with the precipitation system at later time (not shown). The westward-moving precipitation system became long-lived while it continued merging with and strengthened by these eastward moving individual convective cells sequentially. This process is similar to the evolution of a multicell storm and can be explained by the advection mechanism (Lin et al., 1998; Lin \& Joyce, 2001; Lin, 2007 - p276). Compared to the observed radar echoes along L1 (Fig. 4e), the simulated convective cells A-D formed earlier and farther to the coast (Fig. 10).
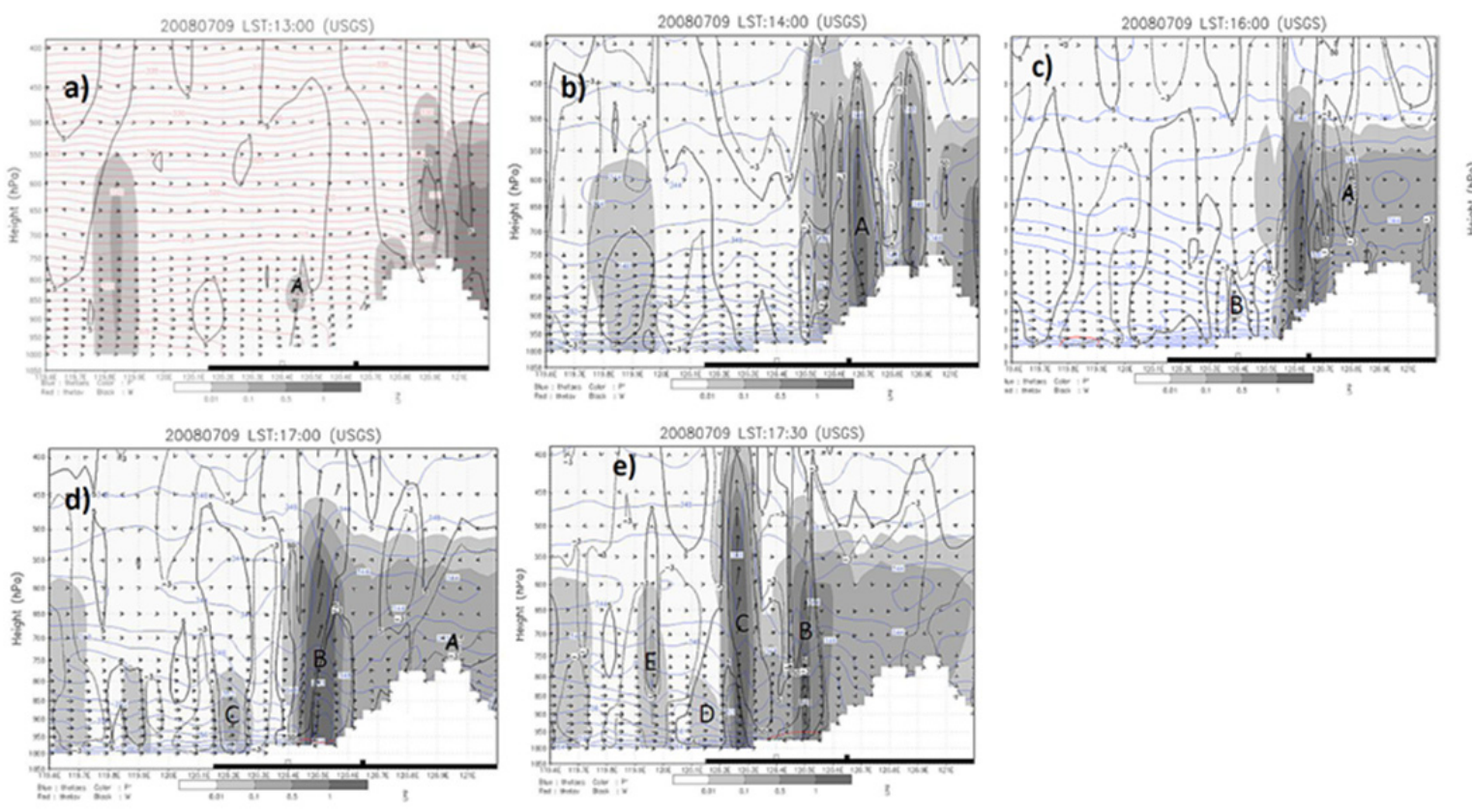

Figure 11. (a) The simulated rainwater mixing ratio (shaded in $\mathrm{g} \mathrm{kg}^{-1}$ ), virtual potential temperature (red contour intervals of $1 \mathrm{~K}$ ), along cross section winds and vertical velocity (black lines at $-2,5,50 \mathrm{~cm} \mathrm{~s}^{-1}$ ) along line L1S in

Fig. 9c from Domain 3 (3 km grid interval) at 7/9/13 LST 2008. (b) Same as (a) but for saturated equivalent potential temperature (blue lines with contour interval of $2 \mathrm{~K}$ ) at 7/9/14 LST. (c) Same as (b) but for 7/9/16 LST.

(d) Same as (b) but for 7/9/17 LST. The virtual potential temperature at $303 \mathrm{~K}$ is represented by a red line. (e) Same as (d) but for 7/9/1730 LST. Wind speed scale is shown at the bottom of the figure. The dark line at the bottom of the figure represents the land. Open and closed squares represent the elevation at 100 and $500 \mathrm{~m}$, respectively. Cells A - E represent the different convection centers

To examine the impact of the low-level evaporative cooling on the development of the precipitation system, we run a case with evaporative cooling deactivated (NEV run). The time evolution of the simulated rainfall along line L1S (depicted in Fig. 9c) over the southwestern Taiwan is shown in Fig. 10b. Similar to the control run (CR run) (Fig. 10a), the precipitation system developed from the mountain ridge to the slope from afternoon to evening. Unlike the CR run, no further cell development is found over the low-land and coastal area. The lack of development in Fig. 10b is in the area where the cold pool or density current was formed along with the simulated precipitation system in CR run (Fig. 10a). Thus, the simulation results confirm the hypothesis proposed in the Introduction. That is, individual convective cells were generated by the cold downslope outflow against the prevailing southwesterly flow which was conditionally unstable with low-Froude number. This made the individual cells propagating downstream (eastward) while the precipitation system was maintained by the continuing merging with convective cells sequentially and propagated upstream (westward). Therefore, the precipitation system fell into Regime I as proposed by Chu \& Lin (2000) and behaved like a multicell storm and can be explained by the advection mechanism (Lin, 2007-p.276). Note that this hypothesis has also been verified by observational analyses performed in section 2 . 


\subsubsection{Case B (18-19 August 2006)}

The simulated low-level synoptic environment on $850 \mathrm{hPa}$ before the formation of long-lived precipitation system at 8/18/08 LST is shown in Fig. 13a. The numerical model is able to reproduce Typhoon Wukong which was well-simulated and located over southwestern Japan, similar to the observation (Fig. 5a). The observed westerly wind in southern Taiwan Strait (Fig. 5a) is also reproduced by the model (Fig. 13a). Around 8/18/12 LST, the simulated rainfall was located over the low-land of western Taiwan (not shown), similar to that observed. At 8/18/16 LST, the simulated rainfall over southwestern slope of CMR (Fig. 14a) moved to southwestern coast and the adjacent ocean (Fig. 14b) at 8/18/18 LST, which is an hour late than the observations (not shown). The simulated rainfall persisted over the southern Taiwan Strait until early morning of 19 August (Fig. 14c). The simulated accumulated rainfall on 18 August (Fig. 14d) shows that there was more (less) rainfall over the southwestern slope of CMR (southwestern coast) than that observed (Fig. 2b.).
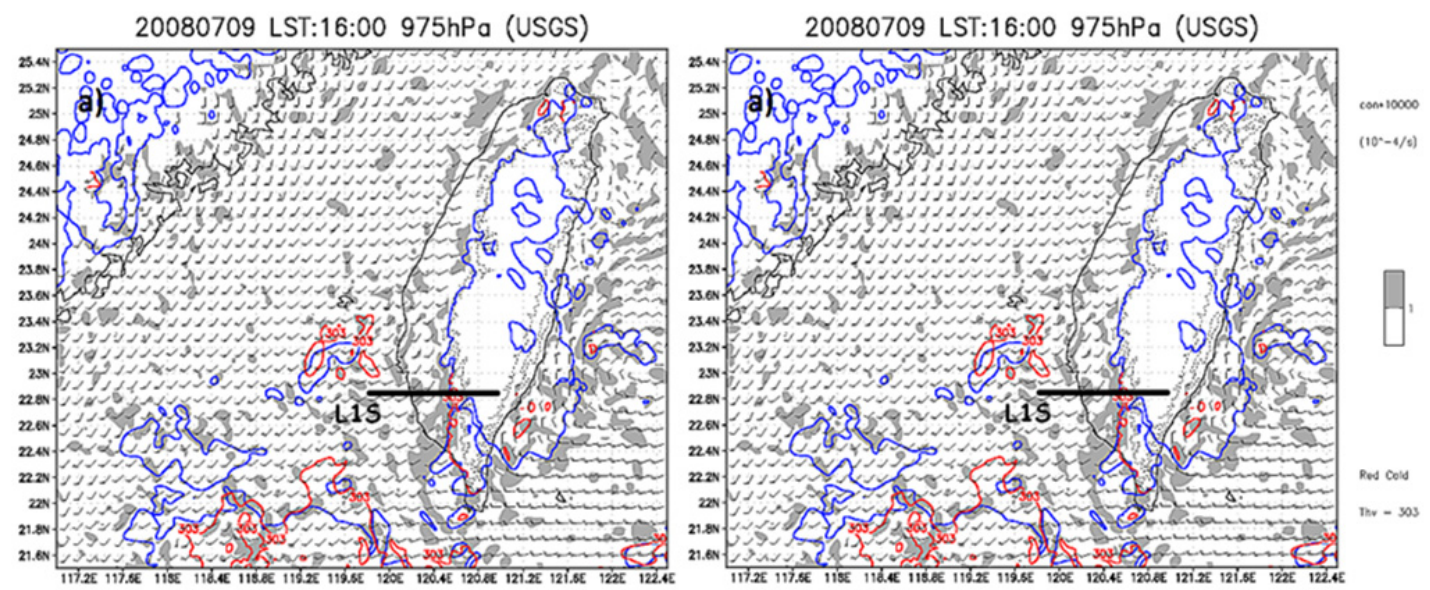

Figure 12. (a) Simulated convergence (shaded areas in $10^{-4} \mathrm{~s}^{-1}$ ) at $975-\mathrm{hPa}$ level from $3 \mathrm{~km}$ grid size at 7/9/16 LST 2008. Blue lines represent the 10 min-rainfall rate exceeding $0.2 \mathrm{~mm}$. The virtual potential temperature at $303 \mathrm{~K}$ is represented by the red lines. The terrain elevation is shown at $500 \mathrm{~m}$ (dashed line). (b) Same as (a) but for 7/9/17 LST
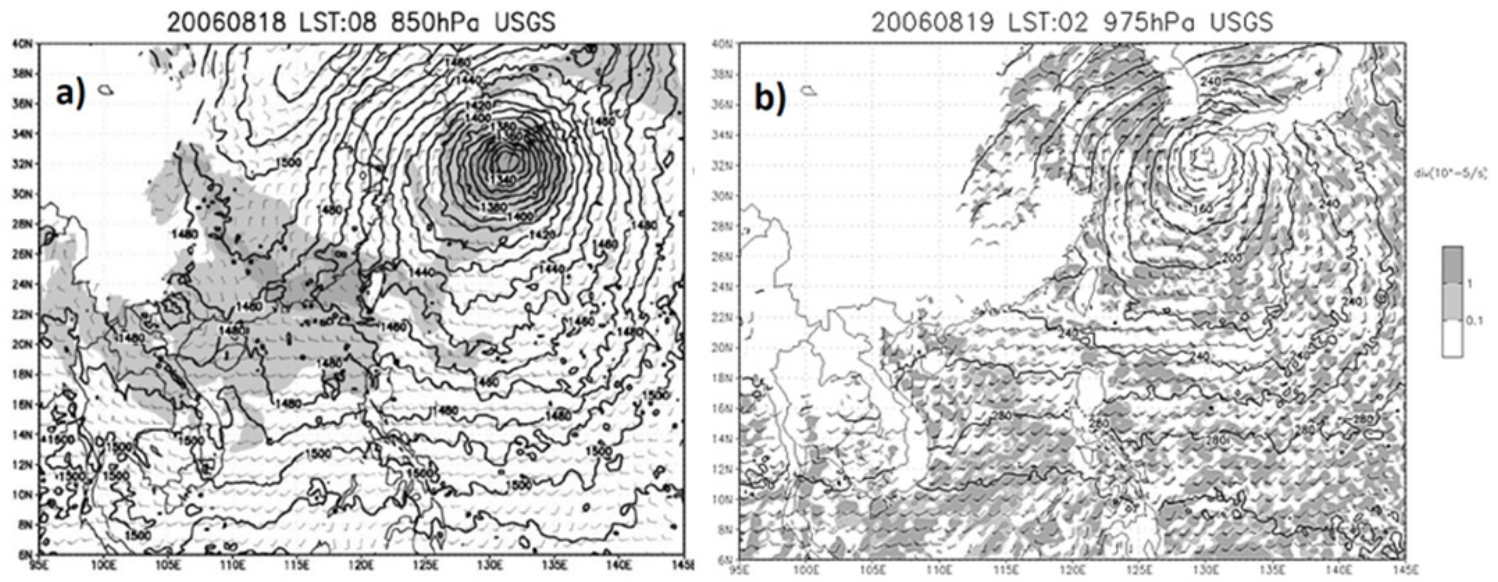

Figure 13. (a) Same as Fig. 8 a but for $8 / 1808$ LST 2006. (b) Same as Fig. 8 b but for 8/19/02 LST

Similar to Case A, the evolution of the long-lived simulated precipitation system over southwestern Taiwan is examined by the variation of the simulated rainfall along L2S (Fig. 14d) and is shown in Fig. 15a. Similar to Case A, a series of convective cells (A-L) formed consecutively and propagated eastward individually, while the precipitation system moved westward and long-lived. At 8/18/12 LST, the simulated convective system formed over the mountainous area. At the same time, cell A formed over the low-land area and moved northeastward 
merging with the precipitation system. The simulated precipitation system intensified over the mountainous area in the afternoon and moved southwestward to Taiwan Strait after 8/18/16 LST. Several convective cells (D, E, F and $G$ ) then developed over the coastal area along the cold pool in the afternoon and merged with the westward moving precipitation system. Over the adjacent ocean, the preexisting cell H jointed by cells I, J, K and L was present in the evening. The westward moving precipitation system from southwestern Taiwan merged with the preexisting cell $\mathrm{H}$ and lasted until the early morning of 19 August to become a long-lasting precipitation system.

In order to investigate the maintenance mechanism of the long-lived precipitation system over southwestern Taiwan, the kinematic and thermodynamic fields along L2S (Fig. 14d) are analyzed (Fig. 16). Similar to Case A, convective cell A formed over a well-mixed boundary layer (not shown) within a conditionally unstable atmosphere at 8/18/11 LST (Fig. 16a) and intensified over slope at 12 LST (Fig. 16b). The well-developed precipitation system over the mountainous area produced a cold pool and interacted with the southwesterly wind, enhancing cell D (not shown) and cell E at 17 LST (Fig. 16c). The merging with cell E prolonged the westward moving precipitation system. The cold pool then developed into density current propagating to the adjacent ocean and strengthened the preexisting convective cells in the early morning (not shown). The formation of the convective cells over southern Taiwan Strait was also reinforced by the low-level convergence due to the simulated northerly wind associated with Typhoon Wukong's (2006) circulation and the simulated prevailing westerly winds (Fig. 13b).

To investigate the impact of the low-level cooling on the development of the precipitation system, a NEV run is performed. The variation of simulated rainfall along line L2S over southwestern Taiwan (Fig. 14d) is shown in Fig. 15b. Similar to Fig. 15a (CR run), the precipitation system developed over the mountain peak and propagated toward the upstream (western) slope in the afternoon. Unlike the CR run, no further development is found over the low-land and coastal area. Similar to case A, convective cells failed to develop due to the lack of evaporative cooling-induced cold pool (Fig. 15b). The numerical simulation confirms the hypothesis that the evaporative cooling-induced cold pool played essential role in the maintenance of the long-lived heavy rainfall system as proposed in section 2 .
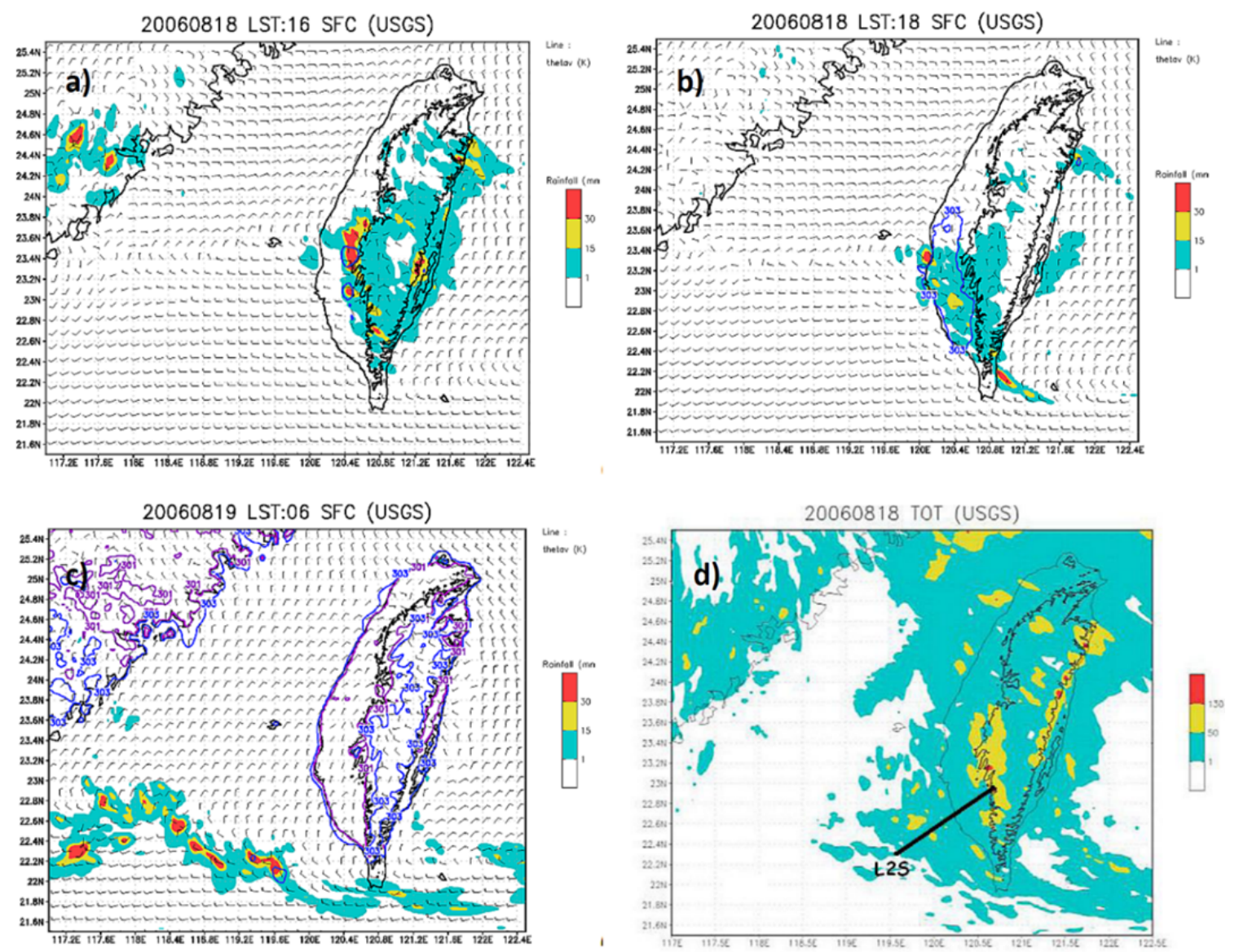

Figure 14. (a) Same as Fig. 9a but for 8/18/16 LST 2006. (b) Same as (a) but for 8/18/18 LST. (c) Same as (a) but for 8/19/06 LST. (d) The simulated accumulated daily rainfall (color bar in $\mathrm{mm}$ ) from $3 \mathrm{~km}$ grid size on 18 
August 2006

\section{Conclusion}

Local rainshowers in summer is one of the main rain producers in Taiwan (Chen \& Chen 2003). Only few rainshowers with heavy rainfall (daily rainfall accumulation exceeding $130 \mathrm{~mm}$ ) can last longer than $10 \mathrm{~h}$. In this study, both long-lived heavy rainfall systems in summer over Taiwan are investigated by performing observational analyses of a variety of data sets, such as the NCEP data, satellite imagery, radar reflectivity, and rainfall data, and the numerical simulations of the synoptic and mesoscale processes using the WRF model. Both the initiation and maintenance mechanisms of these long-lived heavy rainfall systems are explored. The results show that the precipitation systems developed over the western slope of CMR under the low-level southwesterly flow for Case A (9-10 July 2008) or westerly flow for Case B (18-19 August 2006) in the early afternoon. The upper-level flow had easterly wind component. The precipitation systems moved westward toward Taiwan Strait while individual cells moved eastward. The evaporated cooling near surface enhanced the formation and
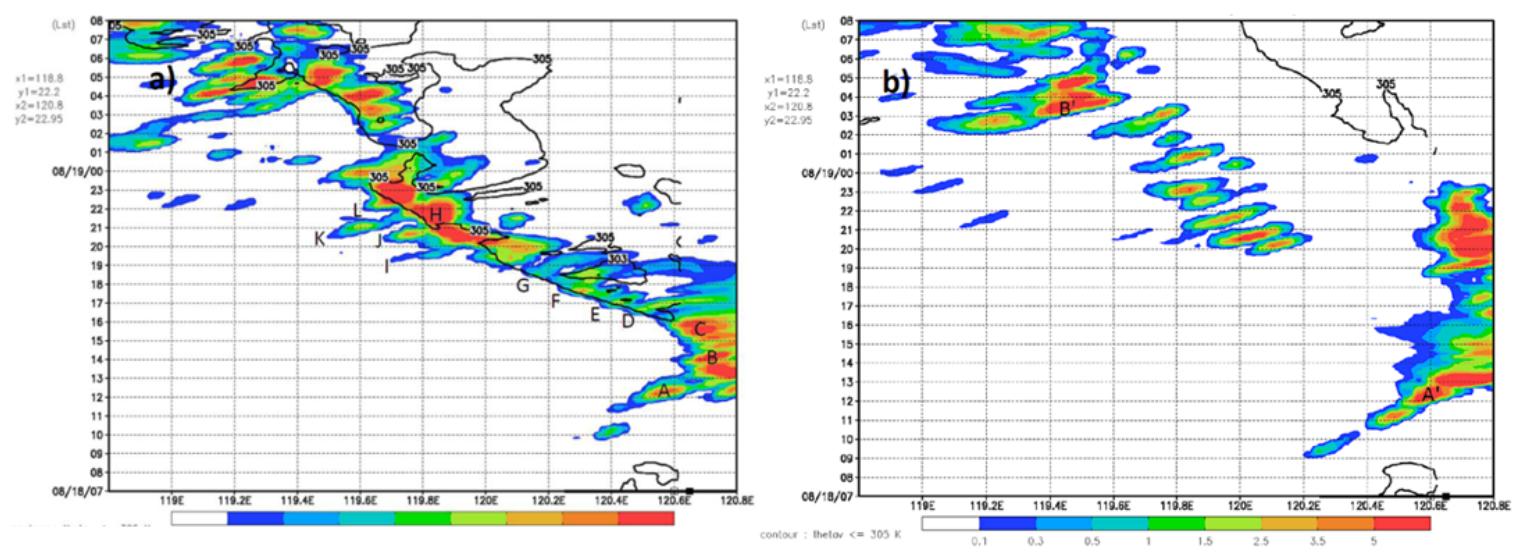

Figure 15. (a) Same as Fig. 10a but for 18-19 August 2006 along L2S in Fig. 14d. (b) Same as (a) but for the NEV run
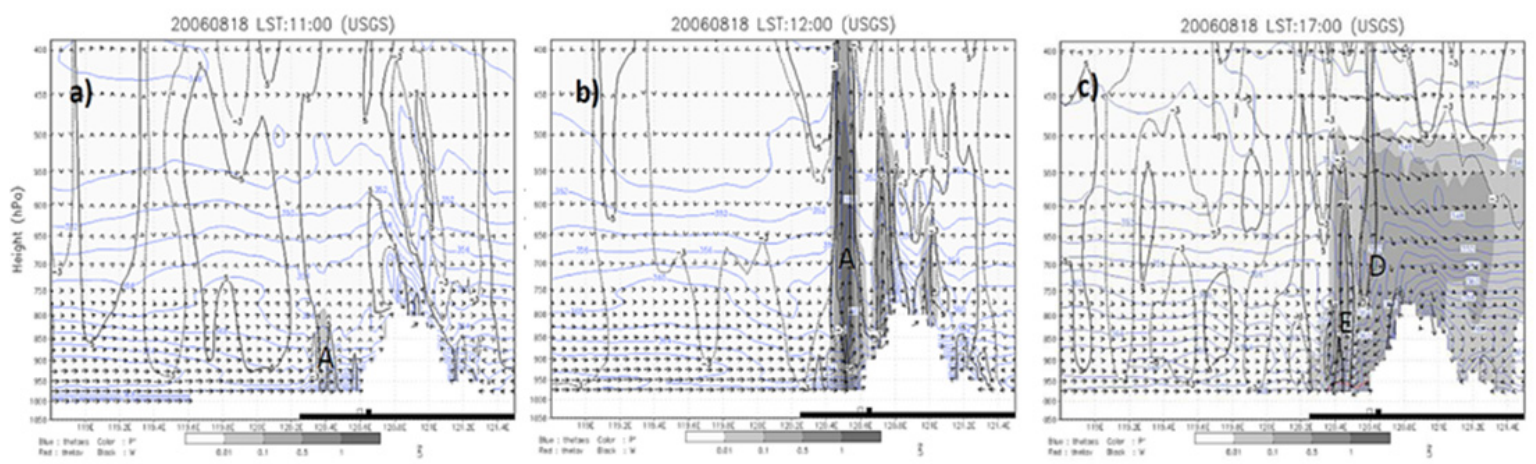

Figure 16. (a) Same as Fig. 11 b but for 8/18/11 LST 2006 along L2S in Fig. 14d. (b) - (c) Same as (a) but for 8/18/12 LST and 8/18/17 LST, respectively 


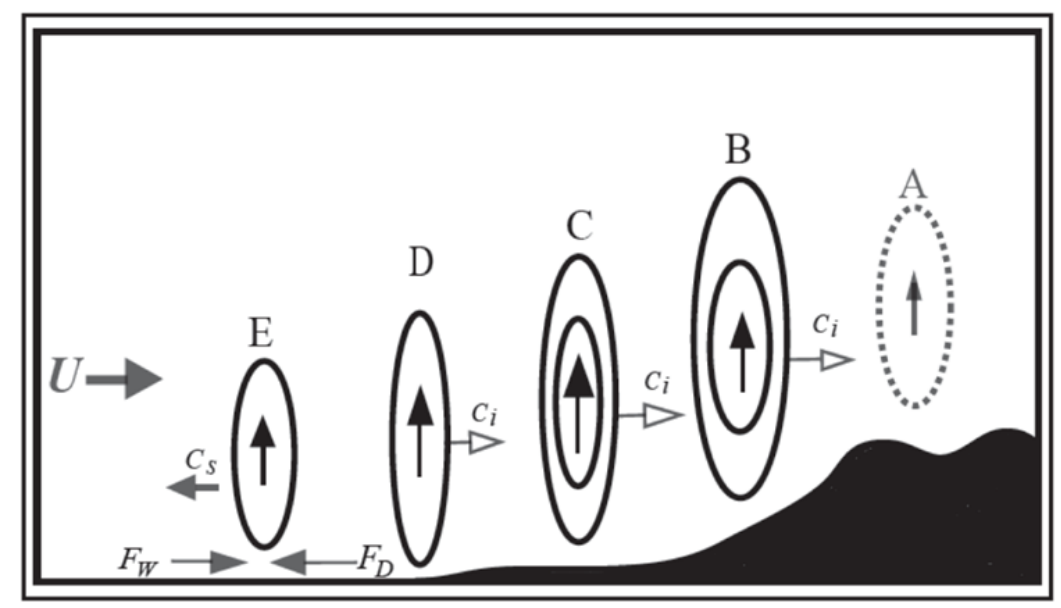

Figure 17. A conceptual model for the initiation and maintenance mechanisms for heavy precipitation systems over a mountainous island under a prevailing wind, which is similar to Regime I of Chen and Lin (2005) and Chu and Lin (2000), and a multicell storm (Lin et al., 1998; Lin and Joyce, 2001) that individual convective cells A-E are generated by the cold downslope outflow against the prevailing southwesterly flow $(U)$ which was conditionally unstable with low-Froude number. This made the individual cells propagating downstream (eastward) with a speed of $\mathrm{C}_{i}$ while the precipitation system was maintained by the continuing merging with convective cells sequentially and propagated upstream (westward) with a speed of $\mathrm{C}_{\mathrm{s}}$. This regime is represented by low-Froude number $\left(F_{w}\right)$ and high CAPE. The forcing associated with the cold outflow, $F_{D}$, is related to the

CAPE

maintenance of individual cell. Because of sequential formation of the convective cells and merged into the original precipitation system, the precipitation system became long-lived. This phenomenon belongs to Regime I, i.e. low-Froude number and high CAPE flow, as proposed by Chen \& Lin (2005) and the formation and propagation in a way are similar to multicell storms (Lin et al., 1998; Lin \& Joyce, 2001). When the precipitation systems moved to the adjacent ocean of southwestern coast of Taiwan, the air of the cold pool converged with the prevailing wind and helped prolong the precipitation system. In addition, the mesoscale low-level convergence over the adjacent ocean of southwestern Taiwan either due to prevailing wind deceleration by CMR or by mesoscale environmental flow also helped the longevity of the prolong precipitation system.

In summary, the initiation and maintenance mechanisms for the current two heavy precipitation systems over a mountainous island under a prevailing monsoon current may be illustrated by a conceptual model (Fig. 17) which is similar to Regime I of Chu \& Lin (2000) and Chen \& Lin (2005) and a multicell storm (Lin et al., 1998; Lin \& Joyce, 2001) that individual convective cells are generated by the cold downslope outflow against the prevailing southwesterly flow which was conditionally unstable with low-Froude number. This made the individual cells propagating downstream (eastward) with a speed of $\mathrm{C}_{i}$ while the precipitation system was maintained by the continuing merging with convective cells sequentially and propagated upstream (westward) with a speed of $\mathrm{C}_{\mathrm{S}}$. This regime is represented by low-Froude number $\left(F_{w}\right)$ and high CAPE. The forcing associated with the cold outflow, $F_{D}$, is related to the CAPE.

\section{Acknowledgments}

This work is supported by the National Science Council of Taiwan under Grant NSC101-2111-M-008-019 and the U.S. National Science Foundation Award AGS-1265783, OCI-1126543, and CNS-1429464. We thank the Central Weather Bureau, Taipei, Taiwan, for providing the data. Michelle Lin's editing of the text is appreciated. The computer resources were supported by the Center for computational Geophysics, National Central University, Chung-Li, Taiwan, under contribution number NCU-CCG100-0014.

\section{References}

Chen, C.-S., \& Chen, Y.-L. (2003). The rainfall characteristics of Taiwan. Mon. Wea. Rev., 131, 1323-1341.

Chen, C.-S., Chen, W.-C., Chen, Y.-L., Lin, P.-L. \& Lai, H.-C. (2005). Investigation of orographic effects on two heavy rainfall events over southwestern Taiwan during the Mei-yu season. Atmos. Res., 73, 101-130.

Chen, C. S., Chen, Y.-L., Liu, C.-L., Lin, P.-L. \& Chen, W.-C. (2007). Statistics of heavy rainfall occurrences in 
Taiwan. Wea. Forecasting, 22, 981-1002.

Chen, C.-S., Lin, Y.-L., Hsu, N.-N., Liu, C.-L. \& Chen, C.-Y. (2011). Orographic effects on localized heavy rainfall events over southwestern Taiwan on 27 and 28 June 2008 during the post-Mei-Yu period. Atmos. Res., 101, 595-610.

Chen, S.-H., \& Lin, Y.-L. (2005). Orographic effects on a conditionally unstable flow over an idealized three-dimensional mesoscale mountain. Meteor. Atmos. Phys., 88, 1-21.

Chen, Y.-L. (2000). Effects of island airflow on rainfall distributions during the Mei-Yu season over Taiwan. Proc. Workshop on numerical simulations of precipitation in Taiwan area. National Central University, Chung-Li, Taiwan, 5-11.

Chu, C.-M., \& Lin, Y.-L. (2000). Effects of orography on the generation and propagation of mesoscale convective systems in a two-dimensional conditionally unstable flow. J. Atmos. Sci., 57, 3817-3837.

Dudhia, J. (1996). A multi-layer soil temperature model for MM5. Preprints, Sixth PSU/NCAR Mesoscale Model Users' Workshop, Boulder, CO, NCAR, 49-50. Retrieved from http://www.mmm.ucar.edu/mm5/mm5v2/whatisnewinv2.html

Grell, G. A., \& Devenyi, D. (2002). A generalized approach to parameterizing convection combining ensemble and data assimilation techniques. Geophys. Res. Lett., 29(14), 1693. http://dx.doi.org/10.1029/2002GL015311

Hong, S. Y., Noh, Y., \& Dudhia, J. (2006) A new vertical diffusion package with an explicit treatment of entrainment processes. Mon. Wea. Rev., 134, 2318-2341.

Houze, R. A., Geotis, S. G., Marks F. D., \& West, A. K. (1981). Winter monsoon convection in the vicinity of north Borneo. Part I: Structure and time variation of the clouds and precipitation. Mon. Wea. Rev., 108, 1595-1614.

Kain, J. S., \& Fritsch, J. M. (1993). Convective parameterization for mesoscale models: The Kain-Fritsch representation of cumulus convection in numerical models. Meteorol. Monogr., 46, Amer. Meteor. Soc., 24, 165-170.

Kerns, B., Chen, Y.-L., \& Chang, M.-Y. (2010). The diurnal cycle of winds, rain and clouds over Taiwan during the Mei-Yu, summer, and autumn regimes. Mon. Wea. Rev., 138, 497-516.

Ko, K.-C. \& Tzeng, Y.-S. (2013). Characteristics of summertime circulation patterns for southern Taiwan's monsoon rainfall from July to September. TAO, 24, 107-119.

Krishtawal, C. M., \& Krishnamurti, T. N. (2001). Diurnal variation of summer rainfall over Taiwan and its detection using TRMM observations. J. Appl. Meteor., 40, 331-344.

Lee, K.-Y. (2012). Terrain effects on three long-lived precipitation system over Taiwan during summer. MS thesis (in Chinese), National Central University, Chung-Li, Taiwan, 177 pp.

Lin, C.-Y., \& Chen, C.-S. (2002). A study of orographic effects on mountain-generated precipitation systems under weak synoptic forcing. Meteor. Amos. Phys., 81, 1-25.

Lin, P.-F., Chang, P.-L., Jou, B. J.-D., Wilson, J. W., \& Roberts, R. D. (2011). Warm season afternoon thunderstorm characteristics under weak synoptic-forcing over Taiwan Island. Wea. Forecasting, 26, 44-60.

Lin, Y.-L. (1993). Orographic effects on airflow and mesoscale weather systems over Taiwan. TAO, 4, 381-420.

Lin, Y.-L. (2007). Mesoscale Dynamics. New York, NY: Cambridge University Press.

Lin, Y.-L., \& Joyce, L. E. (2001). A further study of the mechanisms of cell regeneration, propagation, and development within two-dimensional multicell storms. J. Atmos. Sci., 58, 2957-2988.

Lin, Y.-L., Deal, R. L., \& Kulie, M. S. (1998). Mechanisms of cell regeneration, development, and propagation within a two-dimensional multicell thunderstorm. J. Atmos. Sci., 55, 1867-1886.

Ohsawa, T., Ueda, H., \& Hayashi, T. (2001). Diurnal variations of convective activity and rainfall in tropical Asia. J. Meteor. Soc. Japan, 79, 333-352.

Thompson, G., Field, P. R., Rasmussen, R. M., \& Hall W. D. (2008). Explicit forecasts of winter precipitation using an improved bulk microphysics scheme. Part II: Implementation of a new snow parameterization. Mon. Wea. Rev., 136, 5095-5115.

Wang, S.-Y., \& Chen, T.-C. (2008). Measuring East Asian summer monsoon rainfall contributions by different 
weather systems over Taiwan. J. Appl. Meteor. Climate, 47, 2068-2080.

\section{Copyrights}

Copyright for this article is retained by the author(s), with first publication rights granted to the journal.

This is an open-access article distributed under the terms and conditions of the Creative Commons Attribution license (http://creativecommons.org/licenses/by/4.0/). 